\section{The Rite of the Elephant Duel in Thai-Burmese Military History}

\section{Sunait Chutintaranond ${ }^{1}$}

\begin{abstract}
The tradition of a single combat on elephant back first emerged in Thai history in the $13^{\text {th }}$ century during the Sukhothai period. Before that time, there was no evidence that this tradition was practiced by mainland Southeast Asian rulers. The origin of the elephant duel is still unknown but there is historical interpretation that the Thais and other mainland Southeast Asian warriors had adopted this practice from Sri Lanka. The fight on elephant back is a kind of military ritual observed by pre-modern monarchs of mainland Southeast Asia. With the arrival of modern weapons, particularly fire-arms such as muskets and cannons, the tradition was brought to its end. This is due to the fact that the fighter riding on the back of a huge creature had become a clear target of the opposition gunners. Many of them had been murdered before the engagement. The tradition was terminated in late $16^{\text {th }}$ century. The fight between King Naresuan of Ayudhya and the Crown prince of Pegu had marked the end of this fatal ritual after being practiced without interruption for over three centuries.
\end{abstract}

The elephant, largest and most magnificent of the land animals, has had to pay a high price in war, above all in India.

\footnotetext{
'Director, Thai and Southeast Asian Studies Center, Chulalongkorn University, Bangkok, Thailand.
}

The initial steps in utilizing them for military purposes were probably taken in the post-Vedic period. "In both the Jatakas and the epics the elephant are represented as taking part in military operations." 2 There is, however, clear reference in classical chronicles to the intensive use of elephants in war at about the time the youthful Macedonian king Alexander invaded the upper Indus in the year 376 B.C. The King of Porus opposed the Greek intruders on the Hydaspes, the border of his country, with military forces numbering 50,000 infantry, 3,000 cavalry, 300 war chariots, and about 200 war elephants according to the Greek historian Diodorus, who lived in the $1^{\text {st }}$ century B.C. ${ }^{3}$ Following that the e lephant became the most important arm in Indian military history up until the introduction and increasing use of artillery in the $16^{\text {th }}$ century. ${ }^{4}$ By and large, the functions which a trained elephant corps is expected to perform in war are, according to Kautilya: "(a) acting as the vanguard of a marching army. . . . (b) preparing roads, camping grounds, and landing ghats in rivers. .., (c) clearing away such impediments as small trees and shrubs...., (d) battering down walls, gates and towers of a fortress. . ., and (e) breaking up, scattering or trampling down the hostile force". 5

Jagadish Narayan Sarkar thoroughly formulates the military

${ }^{2}$ P. C. Chakravarit. 1987. The Art of War in Ancient India. pp.47-48.

${ }^{3}$ Karl Groning and Martin Scaller. 1999. Elephant: A Culture and Natural History. pp.198-203.

${ }^{4}$ Jagadish Narayan Sarkar. 1984. The Art of War in Medieval India. pp.107-108.

${ }^{5}$ Chakravarit, p.50. 
functions of this pachyderms as follow: From the days of the Alexander onwards, these were considered to be extremely useful in fighting, - acting as van, protecting flanks and rear, preparing roads and camping grounds, clearing the roads of trees and shrubs, crossing rivers, and breaking the current of swift rivers, strengthening the line of swift rivers, strengthening the line of battle; acting as 'wooden castles' or supplying a lofty and mobile observation post to the King or the Commander enabling him to issue necessary orders or cheer up his army. Hence, tactically speaking, they proved to be good vantage points for commanders. In siege warfare, they, with their heads sheathed in brass or steel plates, served as battering ram .... as rank-breaker ... . when infuriated (mast). Elephants provided with iron sheets or armour. .., carrying iron tower or armour-plated canopied seat . . . supplied with holes, through which soldiers shot arrows, fiery as well as poisonous, and naptha bottles, served the purposes of modern tanks and armouries... and siege machinery . . . A s c arrier, elephants possessed many virtues ... Elephants were used in large numbers carrying musketeers or archers and small cannons. $^{6}$

In comparison with the art of war in premodern India, the use of elephants in war in mainland Southeast Asia was very similar. Simon de la Loube $1 \mathrm{re}$, an extraordinary

${ }^{6}$ Sarkar, p.106. envoy with full powers on the mission sent to A yudhya by K ing L ouise XIV in 1687 , reported that the Siamese (Thais) relied very much upon "the elephants in Combats". According to la Loubêre, every one of the nine battalions had sixteen male elephants in the rear. These elephants were referred to as "Elephants of War". Each of them carried his particular standard and was accompanied by two female elephants. Both male and female creatures were mounted with three armed men each. In addition to Elephants of War, the Thai army had also some "Elephants with Baggage". ${ }^{7}$ Caesar Frederick, a perceptive Venetian traveler in Pegu in the latter half of the $16^{\text {th }}$ century, provides a vivid picture of the utilization of war elephants in Burma during the reign of the warrior king Bayinnaung (1551-81):

It is reported that this King hath four thousand elephant of warre, and all have their teeth, and they use to put on their two uppermost teeth sharpe pikes of iron, and make them fast with $r$ ings, b ecause these beasts fight and make battell with their teeth ... . It is reported that the greatest strength that the King of Pegu hath, is in these Elephants, for when they goe to battell, they set on their backes a Castle of wood bound thereto, with bands under their bellies: and in every Castle foure men very commodiously set to fight with Harquebusses, with Bowes and Arrowes, with Darts and Pikes and other lancing weapons...8

\footnotetext{
${ }^{7}$ Simon de la Loubere. 1986. The Kingdom of Siam. Oxford: Oxford University Press. p.92.

8 Samuel Purchas. (ed.). 1905. Hakluytus Posthumus os Purchas His Pilgrimes. Vol. X, reprinted. pp.122-124: see also Dorothy Woodman. 1962. The Making of Burma. p.19.
} 
In contrast with Indian military custom, in mainland Southeast Asia, elephants were also extensively used for single combat particularly in Burma and Siam. Southeast-Asian warrior kings were very careful in choosing an elephant as their vehical to fight a duel. As a matter of fact, the duel on elephant back was a common practice among warlike Southeast-Asian kings and ranking military generals before and emergence of firearm and the gradual extension of their use. In his famous book on history, Our Wars with the Burmese (Thai rop Prama) Prince Damrong Rajanubhab, the father of modern Thai historical writing, traced the origins of the fight on elephants back to ancient Ceylon, stressing the case of Phra Chao Apaithutsatakhamini (DutthaGemini, 161-137 B.C.), who engaged in single combat on elephants with Phraya Elarathmir (Elara the Tamil). ${ }^{9}$

Precisely when the Thai elephant was first tamed and put to use in the service of humans in single combat is debatable, but it is certain that this traditional form of engagement was not unknown to the Thai kings about 700 years ago. The first record of a duel on elephant back in Thai history occurs in the stone inscription of King Ramkamhaeng of Sukhothai. The King informs the reader that,

"When I was nineteen years old, Khun Sam Chon, the ruler of Muang Chot, came to raid Muang Tak. My father went to fight Khun Sam Chon on the left; Khun Sam Chon charged in, my

\footnotetext{
9 Prince Damrong Rajanubhab. 2001. Our Wars with the Burmese: Thai-Burmese Conflict 1539-1767. English trans. Phra Prison Salarak. Thein Subindu alias U Aung Thein. (ed.) and introduced by Chris Barker. Bangkok: White Lotus. p. 133.
}

father's men fled in confusion. I did not flee. I mounted my elephant and broke the enemy line. I pushed him ahead in front of my father and fought an elephant duel with Khun Sam Chon. I fought Khun Sam Chon's elephant, Mas Muang by name, and beat him. Khun Sam Chon fled. Then my father named me Phra Ramkamhaeng because I fought Khun Sam Chon's elephant". ${ }^{10}$

According to the Ayudhya royal chronicles, there were several occasions when historic encounters on elephant back took place. One of the best known epic battles occurred six months after King Mahachakkraphat of Ayudhaya came to the throne in 1549. It was the time the city was besieged by the army of a Burmese king of Pegu, Tabinshwehti. This battle resulted in the demise of the Chief Queen, Suriyothai ${ }^{11}$, and her daughter, who fought

10 Hosamut Haeng Chat. 1977. Silacharuk Sukhothai Luk thi I Charuk Phokun Ramkamhaeng. p. 9; see also William Warren. 1999. The Elephant in Thai Life and Legend. p. 51.

11 The war between the Ayudhya king, Mahacakraphat (Cakraphat) a nd T abinshwehti was extensively elaborated by early Bangkok chronicle compilers. It is at this period that the demise of an Ayudhya Queen by the name Suriyothai was brought to light. "The British museum Chronicle of Ayudhya", and Ayudhya chronicle unearthed by a senior Thai historian, Mr.Kachorn Sukhabanji, in 1958, for example, depicts the event in detail. According to the chronicle, Queen Suriyothai, who was the chief Queen, dressed herself as the Viceroy or Uparat and accompanied her husband, King Cakraphat, to the battlefield. The King of Ayudhya attemped to make a single duel on the elephant back with Myanmar King. Nevertheless, the royal elephant of the 
with the enemy until she lost her life on the neck of her elephant. ${ }^{12}$ Another historic elephant duel in the history of ThaiBurmese w arfare took place at the B attle of Nong Sarai in 1593. In this battle, the Burmese crown prince of Pegu, Uparacha, was slain on his elephant. ${ }^{13}$

The duel on elephant back is by no means a practice of mortal combat. Several encounters did not cause the

Ayudhya King, at the fighting spot, made a false move, letting the enemy get behind it, and could not maintain its position. The King of Prome, getting behind the the enemy in that way, drove the royal elephant in pursuit of the elephant of King Cakraphat. Queen Suriyothai, seeing that her royal consort has lost his position and would not escape the hands of the enemy, manifested her faithfulness and, weeping, drove out her royal male elephant, Song Suriya Kasat, to rescue him. The Royal elephant of the King of Prome handily got its head up and caused it to lost its position. The King of Prome reached down and slashed with his war scythe, struck Queen Suriyothai on the shoulder and cut down to about her breast. Prince Ramesuan and Prince Mahin forced their royal elephants in to intervene and save their mother but were not in time. As soon as their mother died on the neck of her elephant, the two brothers (Prince Ramesuan and Prince Mahin), retreated to engage the enemy and were able to protect the entrance of the corpse of their mother into the capital. The troops of the capital were routed by the enemy and died in great numbers. However, King Mahacakraphat was able to bring the late Queen Suriyothai, his chief Queen in to the capital and put her royal body in the Municipality of Suan Luang.

${ }^{12}$ David K. Wyatt. (ed.). 2000. The Royal Chronicles of Ayudhya. (trans.). Richard D. Cushman. Bangkok: Siam Society. p. 27.

${ }^{13}$ David K. Wyatt. 1984. Thailand: A Short History. Bangkok: Silkworm Books. pp. 102-103. combatants'deaths. Khun Sam Chon, the ruler of Muang Chot, for instance, escaped from the sword of King Ramkamhaeng; likewise the ruler of Ava, Thadomengsoa, managed to run safely away from the war scythe of his nephew, Nandabayin, the King of Pegu, in a battle of 1584 . Briefly, Thadomengsoa refused to $\mathrm{p}$ ay homage to Nandabayin, the new king of the Burmese empire, who succeeded to the throne on the death of his father Bayinnaung, a great king of the first Toungoo period. As a result, the new king marched on Ava. According to the Burmese Chronicles, "A battle was fought, in which the uncle and nephew, each on his elephant, with a small body of followers, engaged in fierce combat." Finally, the ruler of Ava fled from the battle field and escaped over the Chinese border, where he died soon after. ${ }^{14}$

Both foreign and vernacular accounts reveal the ideology underlying the dueling custom carried out by pre-modern mainland Southeast-Asian kings. It should first be emphasized that, if the king, who in theory was the head of the army and of the kingdom, fell in combat, the battle would suddenly be lost. In the 1593 campaign, Nandabayin's son, Uparacha, was slain; the Burmese army, according to the Ayudhya chronicles, suddenly "fled at the sight, and were once more cut to pieces in a long and terrible retreat". ${ }^{15}$ Therefore, the king would not engage the enemy in the same way ordinary foot and cavalry soldiers did without good reason. For the king, direct contact or engagement was possible only in stylized duels between him and the head of the opposing side who possessed approximately equal status. In

\footnotetext{
${ }^{14}$ Phayre. 1998. History of Burma. pp. $120-$ 121; see also Samuel Puschas. Vol. X, p. 161.

${ }^{15}$ G. E. Harvey. 1967. History of Burma.p. 182.
} 
the Thai-Burmese wars, single combat, the essence of heroic warfare, was not, as previously mentioned, totally unknown. It was, on the contrary, the most honorable and cloudless way for the king to mainfest his courage and prowess as the real cakravartin $^{16}$ on earth. In the case of Thailand and Burma, the kings fought together on elephants in single combat. This type of combat had a functional equivalent in the distant past, b ased on a story in the Mahavamsa, a $6^{\text {th }}$ century Pali chronicle of Sri Lanka, Dutthagamani, fought an elephant duel with a Tamil king from South India in order to protect Buddhism and "to bring glory to the doctrine. ${ }^{\text {"17 }}$ Dutthagamani's heroic warfare became an honorable heritage passed down from his time. Kings of Burma and Thailand who were influenced by the vision of the cakravartin naturally considered the elephant duel of Dutthagamani as a way to manifest themselves as the king of kings of the great Jambudvipa, or Southern Continent.

King Ramkamhaeng of Sukhothai, for example, fought an elephant duel with Khun Sam Chon, the lord of Muang Chot who invaded Sukhothai's western outpost at Tak. On the death of Intraracha, King of

16 The cakravartin (cakkavalti-Pali) is a righteous world ruler whose chariot wheel roll everywhere over the four continents without obstruction. Some Burmese conqueror kings, such as Tabinshwehti (1531-1550), Bayinnaung and Alaungpaya before and during their invasion against Siam or the kingdom of Ayudhya, were influenced by the vision of this ideal Buddhist world ruler.

17 Charles F. Keyes. 1975. "Political Crisis and Militant Buddhism" in Contemporary Thailand: Religion and legitimation of Power in Thailand, Laos, and Burma. (ed.). Bradwell L. Smith. p. 147.
Ayudhya, in 1424, two of his sons contested for the throne in a duel on elephant back, as a consequence of which both died. ${ }^{18}$ Burmese rulers, too, u sed the elephant duel as a means of setting political disputes. When Bayinnaung laid siege to Pegu in 1551, he fought and defeated Smin Htaw, the King of Pegu, in single combat on war elephants. ${ }^{19}$ King Nandabayin and his rebel uncle, the King of Ava, each on his elephant and each with a small body of followers, settled their dispute in fierce combat near Ava in $1584 .^{20}$ In the Thai-Burmese wars, King Mahachakkraphat lost his queen in an elephant-back duel with the King of Prome in 1549. Even Mahachakkraphat's elephant duel, however, is not the most famous and important example of heroic warfare in the history of the hostile relationship between Thailand and Burma. It is the single combat between King Naresuan and the Uparacha of Burma, which has been remembered as the most glorious duel of honor. According to the Luang Prasoet Chronicle of Ayudhya, the fight took place on January 18, 1593 at Nong Sarai, twenty-three kilometers northwest of present-day Suphanburi. A Portuguese account written probably a decade after the incident vividly reveals how the duel was actually fought:

The armies were in sight of each other, and the King of Siam, considering the risk of contending with men favoured by Fortune and mindful of former victories, sought means to avoid a pitched battle. He sent

${ }^{18}$ Wyatt. Thailand.pp. 69-70.

${ }^{19}$ Harvey. History of Burma. p. 163.

${ }^{20}$ Phayre. History of Burma. p. 161; see also Samuel Purchas. Vol. X, p. 161. 
word to the Prince by envoy, that this war was not waged on account of wrongs done by the one Kingdom to the other, or in a public cause in which the subjects were concerned, but merely for the honour which the father claimed in having such a vassal, and which the Prince himself (Uparacha) was to inherit; wherefore it was fitting that he should show himself worthy his own prowess of the glory of such a father, and instead of making the innocent people pay for the personal pretensions of their rulers, should agree to the quarrel being decided by single combat between the young and mettlesome Prince himself and an old and feeble king; on the condition that if the Prince came off victor, the king would do what he commanded him and if the contrary should be the result, he desired nothing more than to part of their kingdoms in friendship, and in the love of the king of Pegu, the Prince's father [Nandabayin].

The young man accepted the challenge on those conditions, and until they should enter on their elephants, picked from among many thousands, the minds of the two mighty armies stood in suspense. Proclamation was made, and as it was impossible for the countless multitude to view the whole combat, the first lines were occupied by the Kings, Princes and Captains, enough by themselves to make two competent armies in our Europe, and the second by the elephants and cavalry, the latter almost crowded out among so many thousands of those castled animals. A suitable space was left in the middle, and in it the two Princes were placed, to the sound of innumerable instrument, upon elephants caparisoned with splendid and costly harness. Nine kingdoms, and the honour they coveted more than all, were the prize of victory. For a long time they contended with admirable valour, till at length the Prince's strength yielded to the king's skill, and he fell pierced by a dart which put an end to the hopes of that imperial monarchy. ${ }^{21}$

Following on this victory in single combat, King Naresuan's fame spread to most of the states in mainland Southeast Asian and beyond. Thereafter, he began conquering all his enemies, carried the war to other

21 “ 'A Brief account of the Kingdom of Pegu' translated from the Portuguese by A. Macgregor, I.C.S., Trpted., with a note by D.G.E.H." in JBRS. 16: 2 (August, 1926), p. 108; O. Frankfurter. "Events in Ayudhya from Chulasakaraj 686-966" in JSS. 6: 3 (1990), p. 24. Nevertheless, Nicolas Pimenta. A Jesuit traveler says that the crown prince of Pegu was killed by a "lead bullet." (Victor B. Lieberman. "How Reliable Is U Kala's Burmese Chronicles? Some New Comparisons" in JSEAS. 17: 2 (September, 1986). pp. 242n. and 245n.) Likewise, U Kala Mahayazawingyi. A Burmese chronicle, says that Uparacha was shot by Siamese Jingle. (Aung Thein. "Intercourse between Burma and Siam as Recorded in Hmannan Yazawindawgyi" in JSS. 8: 2 (1911).p. 50) 
neighboring states, such as Cambodia, Pegu, and Toungoo, and also sent forces to recapture Tavoy and Tenasserim, which were at that time under the sovereignty of the King of Burma; thus did Naresuan extend his ring of power to its fullest extent. ${ }^{22}$ It was also after the elephant-duel victory that Ayudhya gradually regained the political influence it had lost in the previous three decades, since the 1564 war against King Bayinnaung during which Ayudhya was twice defeated. One after another, fiefs of the Burmese king refused to pay the tribute they had been accustomed to surrendering to the court of Burma and turned to receive refuge and patronage from the King of Ayudhya, styling themselves as vassals of Naresuan. ${ }^{23}$ According to Jeremias van Vliet, a Dutch merchant, many cities and states which King Naresuan conquered and seized remained in subjection till the end of his life such as Cambodia, Champa, various cities in Muang Hang (Hamsavadi?), Lan Chang, Chiang Mai, Lakhon (Lampang), Lao, and Kreng (Karen). ${ }^{24}$

One thing is certain; the duel on elephant back was mainly a matter for major figures: kings, members of the royal family, and ranking ministers. It was partially ritualized and restricted to the circle of the ruling class. The prestigious rite of the elephant duel, which was unique in the wide range of combats conducted in the

22 Phraratchaphongsawadan Krung Sayam 1964. pp. 215-311; see also Harvey. History of Burma.p. 182.

\section{${ }^{23}$ Phraratchaphongsawadan Krung Sayam.} pp. 218-20, 257-59, 262.

${ }^{24}$ Jeremias Van Vliet. 1975. The Short History of The Kings of Siam. (tr.). Leonard Andaya. (ed.) David K. Wyatt. p. 87.
Southeast-Asian world finally ceased to be of any value. The increasing use of modern firearms, particularly Portuguese artillery and muskets, from the $16^{\text {th }}$ century onwards reduced the efficacy of the elephants. The lofty elephants made the kings and the commanders riding on their necks easy targets for enemy gunners. It is evident that, since the end of Nong Saria battle in 1593 , the battle that cast the life of the Burmese crown prince, the tradition of the elephant duel died out completely. Not later than the middle of the $16^{\text {th }}$ century, both Thai and Burmese rulers were employing western mercenaries and firearms against each other. Contemporary European accounts show that western mercenaries and their firearms played a decisive role in most Siamese-Burmese battle. ${ }^{25}$ Van Vliet notes that the army of the Maha Uparacha of Pegu which came to besiege Ayudhya in 1593 included Moors, Turks, and Portuguese. ${ }^{26}$ It would be a mistake, however, to conclude that the development of mainland-Southeast-Asian armies, paricuraly those of Burma and Ayudhya, were the result merely of western genius and superiority in the art of warfare. Indeed, local military leaders also had a decisive role in employing western weapons, especially cannon, which were extensively produced for sea battles and which they adopted to local warfare consisting of battles which were primarily on land and in the rivers. Muang Htin Aung, a noted Burmese historian, observers that when in 1541 Tabinshwehti attacked Martaban, a seaport at the mouth of the Salween river ruled by Sawbinnya a Mon overload, he sent many fire rafts

\footnotetext{
${ }^{25}$ See note 7, p. 4, (ed.), p. 214.

${ }^{26}$ Van Vliet. p. 80.
} 
down the river, which destroyed Portuguese and Mon ships in the harbor, and then rafts with bamboo towers built on them, from which musketeers fired into the city. Martaban finally fell, and the king captured a great amount of booty. ${ }^{27}$ Bayinnuang who had not "any Armie of power by Sea but in land", but had many thousand elephants of war, adapted arquebuses to firing from the back of elephants. ${ }^{28}$ King Naresuan of Ayudhya, in fighting against the Burmese in 1587, "put guns [punyai or cannon] on the junks and bombarded the headquaters of the King of Pegu, Nandabayin, who aimed to recapture Ayudhya"

The problem of kings and generals making themselves targets attack by enemy gunners when they mounted these ponderous beasts was illustrated at the battles of Yan Prachian. In 1581, Yan Prachian, probably a ranking official of a previous King of Ayudhya, plotted a revolt against Mahathamracha, the new king installed by Bayinnuang, the King of Pegu. According to Ayudhya chronicles, Yan Prachian came to the field on his elephant but within a short time received a deadly wound from a gun shot fired by a westerner living in Hua Tri township, while the rebels were marching on. ${ }^{29}$ Thirty-seven years earlier, in 1548 , the Uparat, or the crown prince, of a usurping King of Ayudhya, Khun Worawongsa, was assassinated by an ex-military officer, Mun Ratchasaneha, who shot the Uparat off his elephant and killed him. ${ }^{30}$ Thus, on

${ }^{27}$ Maung Htin Aung. 1967. A history of Burma. p. 110.

${ }^{28}$ Maung Htin Aung. 1967. A history of Burma. p. 110; see also Note 4, p. 7.

${ }^{29}$ The Royal Chronicles of Ayudhya. p. 82. a practical level, the Portuguese mercenaries and firearm imported and employed by local Southeast-Asian kings were responsible for the termination of the elephant-duel tradition.

The introduction of firearms and the gradual extension of their use brought an end to the age of elephants and created a new era of Southeast-Asian siege warfare. In the $16^{\text {th }}$ and succeeding centuries, the importance of artillery and muskets continued to mounting higher and higher in mainland- Southeast-Asian military estimation. When Tabinshwehti attacked Ayudhya in 1549, he met with an effective defense led by King Mahachakkraphat and his Portuguese mercenaries.

After an insignificant and unsuccessful expedition against Arakan, a quarrel arose with Siam. In 1548 an immense army, including a company of about 180 Portuguese under James Soarez de Melo, marched against Odia (Ayudhya), the then capital, which is described as being no less than eight leagues in circumference. Here the Burmese met with a decided check. About fifty Portuguese, commanded by James Pereira, formed part of the garrison, and the walls were mounted with many guns of unusually heavy caliber. The siege dragged on; it is stated that the invaders endeavoured to induce Pereira to desert his post but without effect, and at last they were

${ }^{30}$ The Royal Chronicles of Ayudhya. p. 23. 
compelled to make a disastrous retreat out of the country. ${ }^{31}$

Nevertheless, Portuguese firearms did not suddenly take the place of elephants and end the era of the elephant duel. As previously mentioned, both King Nandabayin of Pegu and King Naresuan of Ayudhya experienced single combat on elephant back. It was not until the last decade of $16^{\text {th }}$ c entury, a fter the battle of Nong Sarai in 1593, that this rite of courageous engagement was brought to its end.

\section{References}

Aung Thein, U. 1969. "The Burmese Invasion of Siam, Translated from the Hmannan Yazawin Daugyi", JSS 8: 2 (1911), 1-119; 11: 3 (1914-15), 1-67; 12: 2 (1918), 1-48; 13: 1 (1919), 1-65; Kraw Reprint.

Aung-Thwin, Michael. 1981. "Jambudipa: Classical Burma's Camelot" Contributions to Asin Studies.

Chakravarti, P.C. 1972. The Art of War in Ancient India. Delhi: Oriental Publishers.

Cipolla, Carlo M. 1965. Guns and Sails in the Early Phase of European Expansion 1400-1700. London: Collins.

Damnoen Lekhakun, 1964. Prawat Kantriam Kongtap Thai [History of Tha: Military Operations]. Bangkok.

Damrong Rajanubhab. 1962. Thai rop Phama [Ours Wars with the Burmese]. Bagkok.

Hall, D.G.E. 1926. " 'A Brief Account of the Kingdom of Pegu' translated from the Portuguese by A. Macgregor, I.C.S.

31 J. Horton Ryley. 1899. Ralph Fitch: English's Pioneer to India and Burma. p. 143.
Retd. with a note by D.G.E.H." JBRS, 16: 2 (August, 1926).

Hall, D.G.E. 1928. Early English Intercourse with Burma 1587-1743. London.

Khamhaikan chao Krung Kao [Testimony of the People of the Old Capital]. 1967. Bangkok: Krom Sinlapakon.

Lieberman, Victor B. 1984. Burmese Administrative Cycles: Anarchy and Conquest, C.1580-1760. Princeton: Princeton University Press.

Lieberman, Victor B. 1980. "Europeans, Trade, and the Unification of Burma, C.1540-1620." Orients Extremus, 27: 2 (1980).

Narathip Praphanphong, Prince. 1963. Phongsawadan Phama [Burmese Chronicle], vol.2. Bangkok: Khurusapha.

Parker, Geoffrey. 1988. The Military Revolution: Military Innovation and the Rise of the West, 1500-1800. Cambridge: Cambridge University Press.

"Phraratchaphongsawadan chabap Luang Prasoet" [The Luang Prasoet Chronicle of Ayudhya]. Prachum phongsawadan phak thi 1. 1963. Bangkok: Kaona.

Phraratchaphongsawadan Krung Sayam [The Chronicle of Siam, British Museam Edition]. 1964. Bangkok: Kaona.

Purchase, Samuel. (ed.). 1905. Hakluytus Posthumus or Puschase His Pilgrimis, vol.X Reprint. Glasgow.

Saller, Martin and Photographs by Groning, Kari. 1999. Elephants: A Cultural and Natural History. Konemann Veriagsge sells chaft.

Sarkisyanz, E. 1965. Buddhist Background of the Burmese Revolution. The Hague Martinus Nijhoff.

Strong, John S. 1983. The Legend of King Asoka: A Study and Translation of the Asokavadana. Princeton: Princeton University Press.

Suniat Chutintaranon. Phama rop Thai [Siamese Warface]. Bangkok. 
Suniat Chutintaranon. 1988. "Cakravartin: Ideology Reason and Manifestation of Siamese and Burmese Kings in Traditional Warface (1538-1854)" Crossroads. 4: 1 (Fall, 1988).

Tamra phichaisongkram [Treatise of the Art of War]. Cremation volume for Nang Sanit Noranat. 1969. Bangkok.

Vliet, Jeremias Van. 1975. The Short History of the Kings of Siam. (trans.). Leonard Andaya, (ed.). David K. Wyatt. Bangkok: Siam Society.

Wales, H.G.Quaritch 1952. Ancient South East Asian Warface. London: B.Quaritch,Ltd. 